\title{
Seroprevalence of Hepatitis A Virus (HAV) in Mosul City
}

\author{
Ismail I Daood ${ }^{1}$, Radhwan Hussein Ibrahim ${ }^{2}$ \\ ${ }^{I}$ Assistant Professor, Department of Basic Nursing Sciences, College of Nursing, University of Mosul, Mosul, Iraq, \\ ${ }^{2}$ Professor, Department of Clinical Nursing Sciences, College of Nursing, University of Mosul, Mosul, Iraq
}

\begin{abstract}
Background: Globally, there are about 1.5 million cases showing symptoms each year, with tens of millions likely to become infected. It is more common in areas of the world with poor sanitation and inadequate drinking water. The aim of the study is to identify percentage of the prevalence and distribution of hepatitis A (HAV) among the gender, age group.

Methods: Prospective study was applied in Mosul City for the period between July 2017 to June 2019. A seroepidemiologic survey about hepatitis A virus (HAV) infection was carried out in a group comprising 312 patients, ranging in age from 1year to 60 years, from in the Mosul city. Three $\mathrm{ml}$ of blood were taken from the patients and Serum was separated and stored at $-200 \mathrm{C}$ for the test.

Results: The results of the present study indicate that the total prevalence of type A virus in Mosul was $(21.7 \%)$ and was distributed between males and females (14.4\%) (7.3\%), respectively. The infection rate was the highest in the age group (16-21 years).

Conclusion: According to the results of this study, the city of Mosul may be considered a settlement area for the hepatitis virus infection. So people responsible for health in the city must monitor programs to prevent transmission of the virus, which can be carried out in several ways.
\end{abstract}

Key Words: HVA, Prevalence, Mosul .

\section{Introduction}

Hepatitis A one of the viral disease that attack the liver and cause symptoms ranging from mild/severe. ${ }^{(1-}$ 3) By polluting Food, water or by direct contact with a person who is infected, the infection virus is transmitted. (4-5) Very few people with hepatitis A may die from hepatitis and others can be recovering completely by life time immunity. Unsafe water and poor sanitation and personal hygiene e.g. contaminated hands is considered a major risk of hepatitis A. ${ }^{(6-8)}$ Hepatitis A infection does not cause chronic liver disease and is rarely fatal, as it can cause symptoms of debilitating hepatitis and

\section{Corresponding author : \\ Radhwan Hussein Ibrahim}

at the Department of Clinical Nursing Sciences, College of Nursing, University of Mosul, Mosul, Iraq

Tel: +964-770-1620-882;

E-mail: prof.dr.radhwan@uomosul.edu.iq. acute hepatitis (HP), which result in high mortality. A infection occurs in isolated somebody causa and in epidemics around the world and tends to occur periodically. ${ }^{(9)}$ The epidemic disease caused by food or water contamination can be very widespread, such as the epidemiological billet that swept China-Shanghai in 1988 and infected Three hundred thousand people. Hepatitis A viruses are prevalent in the environment and can resist the production and processing of food commonly used to disrupt and / or control bacterial pathogens. ${ }^{(10)}$ The disease can cause serious economic and social damage to local communities. It may take weeks or months for a patient to recover from his or her work, school, or daily life. It can have serious effects on food establishments that are identified as harboring the virus and their overall domestic productivity. ${ }^{(11)}$ Geographical areas can be classified as high, moderate or low levels of hepatitis A infection. The symptoms of hepatitis are similar to the viruses that cause it, and the symptoms of hepatitis in children are similar to the symptoms of influenza, 
including: (12) fever. Nausea. Vomiting. Anorexia. General fatigue. Stem in the upper right of the abdomen or pain, where the liver is located. Jaundice, this occurs due to the swelling of the liver, in addition to increased backup of the blood in the blood and clogged, leading to change the color of the urine to dark orange, and stool to light yellow or similar to clay color. ${ }^{(13-15)}$ With the possibility of previous symptoms, many children with hepatitis do not have any symptoms, and the absence of symptoms with age is inversely proportional to the increase in the risk of infection without symptoms as the age is smaller. ${ }^{(16)}$ Studies show that only $30 \%$ of children with symptoms younger than 6 are present, most of who appear mildly, and symptoms persist for several weeks in older children. ${ }^{(17-20)}$ Hence, this study was designed to determine the sero-prevalence of antibodies to HAV among HCWs at National Institute for Pharmaceutical Research and Development (NIPRD) in Mosul City, Republic of Iraq.

\section{Method}

A prospective design was applied in the current study. Data were collected for the period between $1^{\text {st }}$ of January 2018- 31 of December, 2018 in Mosul CityIraq. A questionnaire was prepared to gather information related to patients who infected with the virus such as their drinking water quality and sources, toilets used and food preparation as well as the some information related to the family socio economic status and educational level. Agreement of the patient were gathered before they enrolled in the study.

\section{Sample collection}

For serological analysis for HAV ( $3 \mathrm{mls})$ of venous blood was collected from each participant into standard sample bottles. The blood samples were collected by well-trained phlebotomists. The samples were centrifuged at 4,452g for 10 minutes and the recovered plasma were aliquoted into the well-labeled cryovials, and kept into $-400 \mathrm{C}$ freeze until ready for the screening.

\section{Serological Screening}

Serological diagnosis was done using Rapid diagnostic tests (RDTs), for HAV infection the SD BIOLINE (Standard Diagnostic (SD) Inc., Korea) one step HAV test kit was used for detection of HAV infection and HAV antibodies was done using the SD BIOLINE $\mathrm{HCV}$ test kit. This is an immunochromatographic rapid test for the qualitative detection of antibodies specific to HAV in blood with a sensitivity of $100 \%$ and specificity of $99.4 \%$ according to manufacturer's instructions found on the standard operation procedure insert. The seropositive samples to HAsAg detected by RDTs screening were further confirmed by Wesstern blot (Trinity Biotech, Bray, Ireland) according to manufacturer's specifications.

\section{Data analysis}

The data obtained from the study was analyzed using (SPSS) (version 20.0), descriptive statistics were presented in Tables. The Chi-square (X2) test was applied to determine the level of association of the prevalence of HAV among study samples with respect to sex and age distribution associations. Values of $\mathrm{P} \leq$ 0.05 were considered statistically significant.

\section{Results}

The results of the present study indicate that the total prevalence of type A virus in Mosul was (21.7\%) and was distributed between males and females (14.4\%) (7.3\%), respectively. The infection rate was the highest in the age group (16-21 years).

Table ( 1 ) HAV Sero-positivity \& Gender difference

\begin{tabular}{|l|l|l|l|}
\hline Gender & Total & * No. Positive (\%) & No. Negative ( \% ) \\
\hline Male & 59 & $29(47.4)$ & $30(50.8)$ \\
\hline Female & 70 & $14(20)$ & $56(80)$ \\
\hline Total & 129 & $43(33.3)$ & $86(66.7)$ \\
\hline Male & 53 & $6(11.3)$ & $47(88.6)$ \\
\hline Female & 60 & $9(15)$ & $51(85)$ \\
\hline Total & 113 & $15(9.3)$ & $98(86.7)$ \\
\hline
\end{tabular}


Table ( 1 ) HAV Sero-positivity \& Gender difference

\begin{tabular}{|l|l|l|l|}
\hline Male & 27 & $3(11.2)$ & $24(88.8)$ \\
\hline Female & 43 & $7(16.2)$ & $36(83.7)$ \\
\hline Total & 70 & $10(14.2)$ & $60(85.7)$ \\
\hline All total & 312 & $68(21.7)$ & $244(78.3)$ \\
\hline
\end{tabular}

Table 2 : Sero-prevalence of Anti - HAV ( all markers ) and gender difference

\begin{tabular}{|c|c|c|c|c|c|}
\hline \multirow{3}{*}{ Gender } & \multirow{3}{*}{ Total } & IgG - ve & $\operatorname{IgG}+\mathrm{ve}$ & $* \operatorname{IgG}+$ ve & * IgG - ve \\
\hline & & IgM - ve & IgM - ve & $\operatorname{Ig} M+$ ve & $\operatorname{Ig} \mathbf{M}+\mathbf{v e}$ \\
\hline & & $\begin{array}{l}\text { Negative non reactive } \\
\%\end{array}$ & $\begin{array}{l}\text { Reaction or } \\
\text { Vaccination \% }\end{array}$ & Positive or reaction $\%$ & Positive or reaction $\%$ \\
\hline Male & 59 & $19(32.2)$ & $17(28.8)$ & $16(27.2)$ & $7(11.8)$ \\
\hline Female & 70 & $38(54.2)$ & $13(18.5)$ & $15(21.4)$ & $4(5.9)$ \\
\hline Total & 129 & $57(44.1)$ & $30(23.2)$ & $31(24.2)$ & $11(8.5)$ \\
\hline Male & 53 & $27(50.9)$ & $21(39.6)$ & $2(3.7)$ & $3(5.8)$ \\
\hline Female & 60 & $13(21.6)$ & $38(63.3)$ & $5(8.3)$ & $4(6.8)$ \\
\hline Total & 113 & $40(35.4)$ & $59(52.2)$ & $7(6.2)$ & $7(6.2)$ \\
\hline Male & 27 & $18(66.6)$ & $5(18.5)$ & $2(7.4)$ & $2(7.4)$ \\
\hline Female & 43 & $25(58.2)$ & $10(23.3)$ & $5(11.6)$ & $3(6.9)$ \\
\hline Total & 70 & $43(6.1)$ & $15(21.4)$ & $7(10)$ & $5(7.1)$ \\
\hline Total & 312 & $140(44.8)$ & $104(33.3)$ & $45(14.4)$ & $23(7.3)$ \\
\hline
\end{tabular}

Table (3 ) : Age groups distribution of Sero-positivity anti-HAV antibodies

\begin{tabular}{|l|l|l|l|}
\hline \multirow{2}{*}{ Age } & Total & Anti - HAV antibodies & Anti - HAV antibodies \\
\cline { 2 - 4 } & No. Of case & Positive IgM , IgG ( \% ) & Negative IgM , IgG ( \% ) \\
\hline $5-$ Jan & 30 & $9(30)$ & $21(70)$ \\
\hline $10-J u n$ & 36 & $10(27.7)$ & $26(72.3)$ \\
\hline $15-$ Nov & 25 & $6(24)$ & $19(76)$ \\
\hline $16-20$ & 52 & $17(32.6)$ & $143(84.7)$ \\
\hline$>20$ & 169 & $26(15.3)$ & $244(78.3)$ \\
\hline All total & 312 & $68(21.7)$ & $35.4)$ \\
\hline
\end{tabular}




\section{Discussion}

According to world Health Organization, about more four million people infected with HAV are in the milled east region. Due to the armies and political conflicted in these countries the accurate data about HAV Sero-prevalence are very imperfect. ${ }^{(21)}$ One of the these country is Iraq and Especially City of Mosul which attached by for more than three years and the health care system was breakdown. The aim of the present study is to estimate the sero-prevalence of HAV in Mosul City the Capital city of Nineveh Governorate among specific age group. The finding of current study shows that, among 312 patients with a clinical presentation of viral hepatitis, $(21.7 \%)$ had positive serum anti-HAV antibodies. These results mirrors of three years of the poor sanitation, and unsafe water supply as well as bad hygienic situation of the City. According to Turky et.al. ${ }^{(15)}$ the HAV infection is hyper endemic in Iraq with a national estimate of $\operatorname{IgG}$ sero-prevalence rate of $98 \%$ in the 5 th decade and older age group $(41+)$. The result is higher rate than finding of previous studies that conducted in recent years in other Iraqi Province like Basrah, Dehouk and Kirkuk. ${ }^{(22)}$ Safiabadi et.al ${ }^{(23)}$ stated that Hepatitis A is strongly associated with hygiene factors and has increased rates of infection during periods of war and conflict, according to recent statistics of infection in countries such as Iraq, Afghanistan, Yemen and Syria. Similarly to previous studies in Iraq and Kingdom Saudi Arabia, the gender has no significant differences were found between male and female infected. ${ }^{(16)}$

Recommendation: According to the results of this study, the city of Mosul may be considered a endemic area for the hepatitis virus infection. So the stakeholders in the city must monitor programs to prevent transmission of the virus, which can be carried out in several ways.

Conflicts of Interest: None declared.

Funding: There is no funding relevant to this study.

Acknowledgment: The authors wish to thank and acknowledge the members of the Review Board of Ethical Research Committee ,Mosul City for granting us the ethical approval for the study. Finally, the study participants are highly appreciated for their valuable time and support.

\section{References}

1. Naoumov NV. Hepatitis A and E. Medicine 2007;35:35-8.
2. Jacobsen KH, Wiersma ST. Hepatitis A virus seroprevalence by age and world region, 1990 and 2005. Vaccine 2010;28:6653-7.

3. Fiore AE, Wasely A, Bell BP. Prevention of hepatitis A through active or passive immunization. MMWR Recomm Rep 2006;55:1-23.

4. Melhem NM, Talhouk R, Rachidi H, Ramia S. Hepatitis A virus in the Middle East and North Africa region: a new challenge. J Viral Hepat 2014;21:605-15.

5. UNHCR. Syrian regional refugee response interagency information sharing portal. UNHCR 2014; Available at: http://data.unhcr.org/syrianrefugees/ regional.php (accessed May 5, 2014).

6. The Lebanese Ministry of Public Health (MOPH) 2014. Available at: http://www.moph.gov.lb/Pages/ Home.aspx (accessed May 20, 2014).

7. WHO position paper on hepatitis A vaccines: June 2012-recommendations. Vaccine 2013;31:285-6.

8. World Health Organization. The global prevalence of hepatitis A virus infection and susceptibility: a systematic review. Geneva, Switzerland: WHO; 2009.

9. Al Faleh F, Al Shehri S, Al Ansari S, Al Jeffri M, Al Mazrou Y, Shaffi A. Changing patterns of hepatitis A prevalence within the Saudi population over the last 18 years. World J Gastroenterol 2008;14:73715.

10. Alkhalidi J, Alenezi B, Al-Mufti S, Hussain E, Askar H, Kemmer N. Seroepidemiology of hepatitis A virus in Kuwait. World J Gastroenterol 2009; 15:102-5.

11. Sharar Z, Rajah J, Parsons H. Childhood seroprevalence of hepatitis A in the United Arab Emirates. Trop Doct 2008;38:65-6.

12. Alian S, Ajami A, Ghasemian R, Yadegarinia D. Age-specific seroprevalence of hepatitis A in Sari, northern Islamic Republic of Iran. East Mediterr Health J 2011;17:754-8.

13. Ardakani A, Soltani B, Sehat M, Namjoo S, Haji Rezaei M. Seroprevalence of antihepatitis A antibody among 1-15 year old children in KashanIran. Hepat Mon 2013;13:e10553.

14. Merat S, Rezvan H, Nouraie M, Abolghasemi H, Jamali R, Amini-Kafiabad S, et al. Seroprevalence and risk factors of hepatitis A virus infection in 
Iran: a population based study. Arch Iran Med 2010;13:99-104.

15. Turky AM, Akram W, Al-Naaimi AS. Analysis of acute viral hepatitis (A and E) in Iraq. Global J Health Sci 2011;3:70-6.

16. El-Gilany AH, Hammad S, Refaat K, Al-Enazi R. Seroprevalence of hepatitis A antibodies among children in a Saudi community. Asian Pacific J Trop Med 2010;3:278-82.

17. Deveci U, Ustun C, Hamanca O. Seroprevalence of hepatitis-A virus among children aged 1-16 years in Eastern Anatolia, Turkey. Afr J Microbiol Res 2011;5:5969-71.

18. Ince OT, Yalcin SS, Yurdako"k K, Ozmert EN. Hepatitis A seroprevalence among infants aged 12 months in Ankara. Turk J Pediatr 2011;53:114-6.

19. Topal E, Hatipoglu N, Turel O, Aydogmus C, Hatipoglu H, Erkal S, et al. Seroprevalence of hepatitis $\mathrm{A}$ and hepatitis $\mathrm{A}$ vaccination rate in preschool age in Istanbul urban. J Pediatr Infect 2011;5:12-5.

20. Ceran N, Yü ksel Kocdogan F, Mert D, Erdem I, Dede B, Adaleti R. Hepatitis seroprevalence in children and young adults in Istanbul, Turkey: seroprevalence change and associated factors. J Viral Hepat 2012;19:72-6.

21. Ghasemian A .Prevalence of hepatitis A across various countries in the Middle East,African and Eastern European countries. Caspian J Intern Med 2016; 7(4):302-303

22. Lavanchy D. Viral hepatitis: global goals for vaccination. J Clin Virol 2012;55:296-302.

23. Safiabadi $M$, Rezaee-Zavareh $M$, and Alavian $\mathrm{S}$.Estimation of Hepatitis A Virus Infection Prevalence Among Eastern Mediterranean and Middle Eastern Countries: A Systematic Review and Pooled Analysis. Hepat Mon. 2017 February; 17(2):e44695. doi: 10.5812/hepatmon.44695. 